\title{
Decomposition of mangrove roots: Effects of location, nutrients, species identity and mix in a Kenyan forest
}

\author{
Mark Huxham ${ }^{\mathrm{a}, *}$, Joseph Langat ${ }^{\mathrm{a}}$, Fredrick Tamooh ${ }^{\mathrm{b}, 1}$, Hilary Kennedy ${ }^{\mathrm{c}}$, Maurizio Mencuccini ${ }^{\mathrm{d}}$, \\ Martin W. Skov ${ }^{c}$, James Kairo ${ }^{\mathrm{e}}$

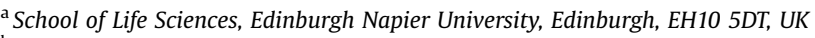 \\ ${ }^{\mathrm{b}}$ Kenya Wildlife Services, P.O. Box 82144-80100, Mombasa, Kenya \\ ${ }^{\mathrm{S} S}$ chool of Ocean Sciences, University of Wales Bangor, Anglesey, LL59 5AB, UK \\ d School of GeoSciences, The University of Edinburgh, Grant Institute, The King's Buildings, West Mains Road, Edinburgh EH9 3JW, UK \\ ${ }^{\mathrm{e}}$ Mangrove Reforestation Program, Kenya Marine and Fisheries Research Institute P. O. Box 81651, Mombasa. Kenya
}

\section{A R T I C L E I N F O}

\section{Article history:}

Received 14 December 2009

Accepted 17 March 2010

Available online $\mathrm{xxx}$

\section{Keywords:}

mangrove

roots

carbon

decay

nitrogen

species-mixing

\begin{abstract}
A B S T R A C T
Mangrove trees may allocate $>50 \%$ of their biomass to roots. Dead roots often form peat, which can make mangroves significant carbon sinks and allow them to raise the soil surface and thus survive rising sea levels. Understanding mangrove root production and decomposition is hence of theoretical and applied importance. The current work explored the effects of species, site, and root size and root nutrients on decomposition. Decomposition of fine $(\leq 3 \mathrm{~mm}$ diameter) and coarse ( $>3 \mathrm{~mm}$ diameter, up to a maximum of $\sim 9 \mathrm{~mm}$ ) roots from three mangrove species, Avicennia marina, Bruguiera gymnorrhiza and Ceriops tagal was measured over 12 months at 6 sites along a tidal gradient in Gazi Bay, Kenya. C:N and P: $\mathrm{N}$ ratios in fresh and decomposed roots were measured, and the effects on decomposition of root size and age, of mixing roots from $A$. marina and $C$. tagal, of enriching $B$. gymnorrhiza roots with $\mathrm{N}$ and $\mathrm{P}$ and of artefacts caused by bagging roots were recorded. There were significant differences between species, with 76, 47 and $44 \%$ mean dry weight lost after one year for A. marina, B. gymnorrhiza and C. tagal respectively, and between sites, with generally slower decomposition at dryer, high tidal areas. $\mathrm{N}$ enriched B. gymnorrhiza roots decomposed significantly faster than un-enriched controls; there was no effect of $\mathrm{P}$ enrichment. Mixing A. marina and $C$. tagal roots caused significantly enhanced decomposition in $C$. tagal. These results suggest that $\mathrm{N}$ availability was an important determinant of decomposition, since differences between species reflected the initial C: $\mathrm{N}$ ratios. The relatively slow decomposition rates recorded concur with other studies, and may overestimate natural rates, since larger $(10-20 \mathrm{~mm}$ diameter), more mature and un-bagged roots all showed significantly slower rates.
\end{abstract}

(ㄷ) 2010 Published by Elsevier Ltd.

\section{Introduction}

Mangrove forests retain large amounts of organic material, often in the form of peat. Roots are a major component of mangrove peat (Mckee and Faulkner, 2000) hence high rates of root production contributes to peat accumulation. Retention of organic matter in mangroves is important at ecosystem and global scales. Mangroves rely on surface level elevation, driven by peat and sediment accumulation, in order to remain above sea level. Biogenic processes of land building, dependent on root production, are particularly relevant in areas without significant allochthonous input (Briggs, 1977;

\footnotetext{
* Corresponding author.

E-mail address: m.huxham@napier.ac.uk (M. Huxham).

1 Current address: Katholieke Universiteit Leuven, Department of Earth and Environmental Sciences, Kasteelpark Arenberg 20, 3001 Leuven, Belgium.
}

McKee et al., 2007; Cahoon et al., 2003). Predictions of sea level rise of up to or exceeding $59 \mathrm{~cm}$ within the next century (IPCC, 2007) emphasise the importance of this process in the future survival of mangroves. Mangroves are estimated to account for $\sim 15 \%$ of the total carbon accumulating in marine sediments (Jennerjahn and Ittekkot, 2002). The processes controlling this accumulation, including peat production, thus play a significant role in the global carbon cycle (Duarte et al., 2005; Bouillon et al., 2008).

Mangroves allocate a relatively large proportion of their total carbon budget to root production (Briggs, 1977; Tamooh et al., 2008). High root: shoot ratios may reflect unstable substrates or water stress related to hyper salinity; for example, Saintilan (1997) reported ratios as high as 4.1 in high tidal high salinity areas. Although such figures are extreme, most estimates show root: shoot ratios in excess of 0.3 (Tamooh et al., 2008). Such large absolute and relative allocation of carbon to the roots does not on 
its own ensure that mangroves function as carbon sinks; for this to happen the rate of organic production and trapping in the system must exceed that of carbon loss. A key determinant of this ratio will be the decomposition rate of mangrove roots. To our knowledge, only six studies have explicitly measured mangrove root decomposition rates (Albright, 1976; Van der Valk and Attiwill, 1984; Mckee and Faulkner, 2000; Middleton and McKee, 2001; McKee et al., 2007; Poret et al., 2007). These concur in recording approximately $50 \%$ loss of mass after one year of decomposition, rates that are much lower than the average for fine roots in terrestrial trees from similar latitudes (Silver and Miya, 2001).

A number of factors are likely to influence decomposition rates, including site (Mckee and Faulkner, 2000), mangrove species (Mckee and Faulkner, 2000; Middleton and McKee, 2001) and root size class (Van der Valk and Attiwill, 1984). These three factors were investigated in the present study at Gazi Bay, Kenya. Differences in nutrient concentrations in plant tissue and in contiguous soil may explain some of the variation observed between species (Feller et al., 1999); the effects of nutrient enhancement on decomposition rates were therefore also considered in the current study. The mixing of materials with different concentrations of nutrients is one mechanism invoked to explain changes in decomposition rates observed in mixed, compared with single species, litters. Whilst numerous studies have examined the effects of species diversity on decomposition using leaves from terrestrial trees (e.g. Madritch and Cardinale, 2007), none have looked at mangrove roots. The effects of mixing roots of species with different nutrient concentrations were therefore also examined, along with the effects of root age and of faunal consumption. Hence the overall aim of this study was to investigate the rates of root decomposition of three species of mangrove, with specific objectives of examining the effects of site, species, nutrient content, root age, root size, faunal consumption and artefacts caused by bagging on the recorded rates of decomposition.

\section{Methods}

\subsection{Field site}

The study was conducted at Gazi bay $\left(4^{\circ} 25^{\prime} \mathrm{S}\right.$ and $\left.39^{\circ} 50^{\prime} \mathrm{E}\right)$ situated on the south coast of Kenya, about $50 \mathrm{~km}$ from Mombasa
(Fig. 1). The bay is sheltered from strong waves by the Chale Peninsula to the east and a fringing coral reef to the south, and has a spring tidal range of $\sim 4.0 \mathrm{~m}$. Total annual precipitation $(1000-1600 \mathrm{~mm})$ falls mainly in two rainy seasons (April-August and October-November) and two seasonal rivers drain into the bay. Air temperature is $24-39^{\circ} \mathrm{C}$ and relative humidity averages $95 \%$. All the nine species of mangroves occurring in Kenya are found in Gazi bay.

\subsection{Experimental transect}

Six stations were established along a $\sim 700 \mathrm{~m}$ transect running down the shore within a continuous mangrove forest. Station 1 (the highest station) was placed within a mixed Avicennia marina/Ceriops tagal stand, at a height of $2.99 \mathrm{~m}$ above chart datum (Table 1 ). This high station is inundated by the sea only at spring tides (inundation class IV of Watson (1928)), and the surface sediment often dries out during neaps. Station 6 was placed in a Sonnaratia alba stand at $1.32 \mathrm{~m}$ above chart datum, and received daily inundation (i.e. Watson class I). Intermediate stations covered the range of heights between these ends, and were situated in areas with four different mangrove species; those given above and Rhizophora mucronata. At each station, three sediment cores were taken at random points using a D-section corer (which encloses an uncompressed sediment core in a sample chamber). A redox meter was used to give sediment redox at $20 \mathrm{~cm}$ depth, and pore water was extracted and tested for salinity using a Refractometer. Average tree height and density within a $10 \times 10 \mathrm{~m}$ area were also recorded (Table 1 ). Data on sediment nutrient concentrations at $5-20 \mathrm{~cm}$ depths are available for Gazi sites close to the current ones (Middelburg et al., 1996). Sediment total nitrogen (wt \%) and phosphorus (ppm) values were $0.08,124 ; 0.14,74 ; 0.10,253 ; 0.03,44$ (nitrogen, phosphorus respectively) at four sites (AS, CC, RJ and SII; Middelburg et al., 1996) similar to sites $1,3,4$ and 6 in the current study.

\subsection{Experimental treatments}

Ten treatments, using roots from three mangrove species (Avicennia marina, Bruguiera gymnorrhiza, and Ceriops tagal) were
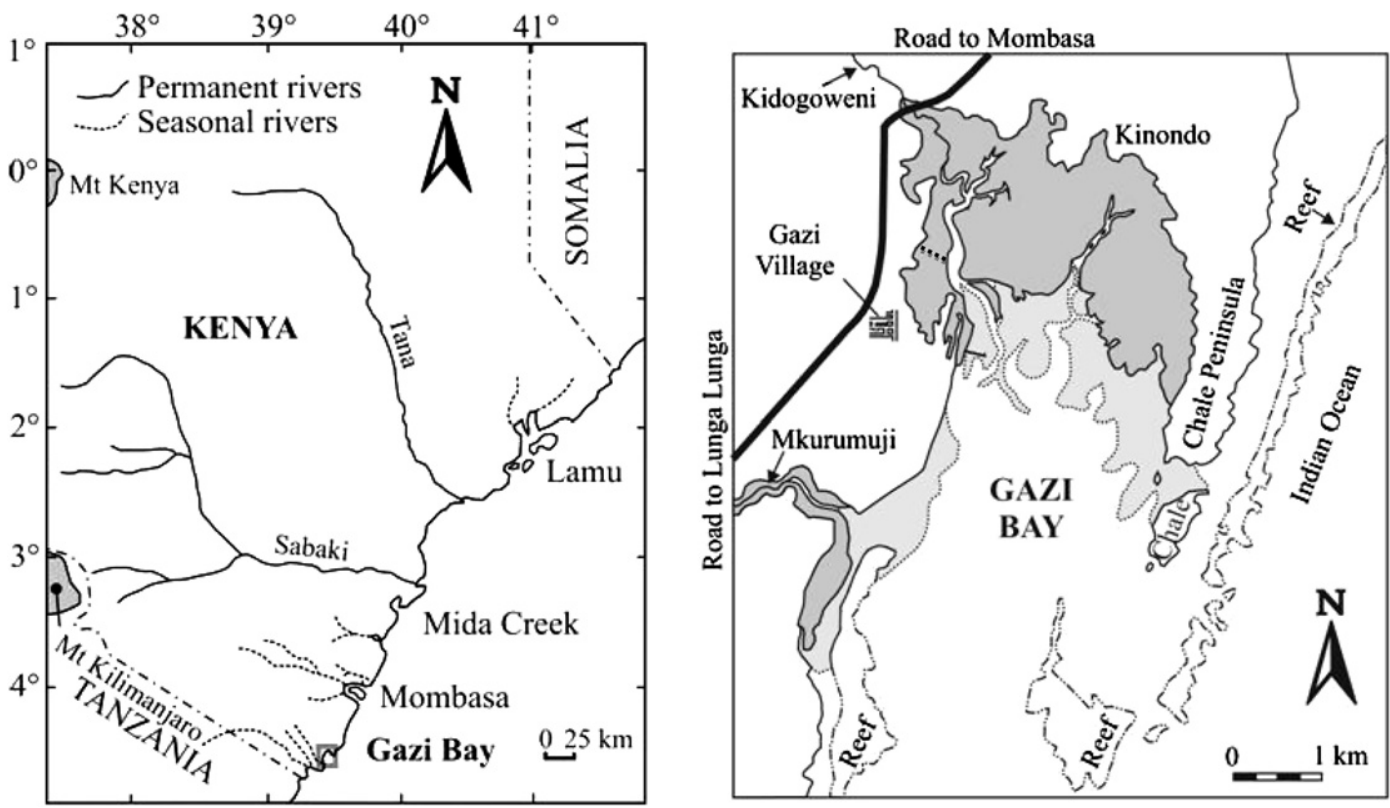

Fig. 1. The study area: dark grey shade = mangroves; light grey= seagrass formation; dashed line indicates location of transect (modified from Bosire et al., 2003). 
Table 1

Description of stations on a transect from high to low shore. Redox and salinity data are means of three samples taken at $20 \mathrm{~cm}$ depth.

\begin{tabular}{llllll}
\hline Site & $\begin{array}{l}\text { Redox } \\
(20 \mathrm{~cm})\end{array}$ & $\begin{array}{l}\text { Salinity } \\
(20 \mathrm{~cm})\end{array}$ & $\begin{array}{l}\text { Tree } \\
\text { density } \\
\left(\mathrm{m}^{2}\right)\end{array}$ & $\begin{array}{l}\text { Tree species } \\
(\text { dominant first })\end{array}$ & $\begin{array}{l}\text { Height above } \\
\text { chart datum }(\mathrm{m})\end{array}$ \\
\hline 1 & 108 & $59^{\mathrm{a}}$ & 0.55 & C. tagal, A. marina & 3.00 \\
2 & 44 & 53 & 0.61 & C. tagal, A. marina & 2.88 \\
3 & 50 & 53 & 2.04 & C. tagal & 2.74 \\
4 & -55 & 34 & 0.40 & R. mucronata & 2.34 \\
5 & -159 & 36 & 0.10 & A. marina, R. mucronata & 2.29 \\
6 & -124 & 32 & 0.16 & S. alba & 1.37 \\
\hline
\end{tabular}

${ }^{\mathrm{a}}$ Mean from similar nearby sites.

prepared: A - Avicennia only; B - Bruguiera only; C - Ceriops only; AC - Avicennia and Ceriops; Bn - Bruguiera and nitrogen; Bp Bruguiera and phosphorus; Cc - crab control; Gc - growth control; Am - Avicennia mature; Al - Avicennia large. These species were used because of their common occurrence at the site and because roots were available from seedlings of the same age and grown under the same conditions; roots for A, B, C, AC, Bn and Bp treatments were taken from 12-month-old seedlings grown in nurseries close to the site (to allow comparisons between these treatments unconfounded by differences in age or growth site). Roots were washed clean of soil and air dried for $6 \mathrm{~h}$ before separation into two size categories, fine ( $\leq 3 \mathrm{~mm}$ diameter) and coarse ( $>3 \mathrm{~mm}$ diameter, up to a maximum of $\sim 9 \mathrm{~mm}$ ). A random sample of $\sim 20 \mathrm{~g}$ of roots of each size category for each species was removed and oven dried at $60^{\circ} \mathrm{C}$ for $48 \mathrm{~h}$ for derivation of wet to dry weight conversions (to allow estimates of the initial dry weights of the wet roots that were buried).

For A, B and C treatments, $15 \mathrm{~g}$ of root material, consisting of $5 \mathrm{~g}$ fine and $10 \mathrm{~g}$ coarse roots (reflecting the natural ratio between these root sizes) from the relevant species, was placed into $1 \mathrm{~mm}$ mesh fiberglass bags. The AC treatment was designed to test for any effects of mixing species on decomposition rates: a total of $15 \mathrm{~g}$ root material was made up of $2.5 \mathrm{~g}$ fine roots from both Avicennia and Ceriops, along with $5 \mathrm{~g}$ coarse material from each species. Bn and Bp treatments were established to examine the effects of enhanced tissue nutrients on decomposition. They were the same as $\mathrm{B}$, but were taken from plants fertilized four months previously with commercial 'Vitax' nitrogen (20\% ammoniacal nitrogen) and phosphorus (17\% phosphorus pentoxide) fertilizer, respectively. The Am treatment was the same as A, but was designed to examine the effects of plant maturity on decomposition, so consisted of roots taken from 12-year-old trees in a nearby plantation. The Al treatment was designed to examine the effects of size on decomposition rates, and consisted of $20 \mathrm{~g}$ of large $(10-20 \mathrm{~mm}$ diameter) roots taken from plantation trees; this size category is the largest commonly found in natural Avicennia marina stands at Gazi Bay (Tamooh et al., 2008). The Cc treatment was included to test for artefacts caused by the mesh bags, in particular for the possibility that the bags could exclude fauna such as crabs that are active in the decomposition process. It consisted of $15 \mathrm{~g}$ coarse Bruguiera roots, taken from the same seedlings used for the B treatment, placed into a bundle, and tied with thin nylon line at one end, fixed to the roots using a small drop of epoxy resin. Finally the Gc treatment was designed to examine any artefacts caused by the growth of nearby roots into the mesh bags. It consisted of mesh bags filled with sandy sediment taken from station 1 , from which any mangrove roots had been carefully removed.

Total replication for each treatment was: $\mathrm{A}, \mathrm{B}, \mathrm{C}, \mathrm{AC}, \mathrm{Al}$, and $A m=36 ; B n, B p=12 ; C c, G c=6$. At each station on the transect two blocks were established $\sim 10 \mathrm{~m}$ apart. Plots within blocks, separated by $50 \mathrm{~cm}$ and marked with small plastic rods, were randomly allocated to treatments with three replicates per treatment per block (i.e. six replicates per station). Cc and Gc treatments were placed at station 4 only, Bn and Bp at stations 1 and 6 only and all other treatments were placed at all stations. Root bags (and bundles, for Cc treatments) were buried in August 2006 by making a $20 \mathrm{~cm}$ deep slot and placing the bags vertically (hence the depth of roots ranged from $20 \mathrm{~cm}$ to $10 \mathrm{~cm}$ ).

\subsection{Root recovery and processing}

At each station, all the plots in one block were sampled six months after burial in February 2007 (giving $n=3$ per treatment per station). Particular care was taken to remove the Cc treatment, since the roots were not bagged; the nylon filament had been tied to a stick at the sediment surface and was used to find the roots that were then carefully extracted. In the laboratory, sediment was carefully washed away from the root bags before they were opened, and roots were air dried before being separated into size (and for AC treatments into species; the two species were still distinguishable by eye) categories and weighed. Dry weights were recorded after oven drying at $60{ }^{\circ} \mathrm{C}$ for $48 \mathrm{~h}$.

The remaining plots were sampled 12 months after burial, in July 2007, and samples treated the same as in February.

\subsection{Organic carbon, nitrogen, and phosphorus analyses}

Dried and ground, homogenized root material was weighed into pre-combusted silver boats $\left(500{ }^{\circ} \mathrm{C}, 3 \mathrm{~h}\right)$, and carbonate material was removed through a combination of $\mathrm{HCl}(10 \%)$ additions and drying at $\sim 50^{\circ} \mathrm{C}$. The organic carbon $\left(\mathrm{C}_{\mathrm{org}}\right)$ and total nitrogen $\left(\mathrm{N}_{\text {total }}\right)$ concentrations of the mangrove roots were determined on a CARLO ERBA NA 1500 Elemental CHN Analyzer. The P content was measured on unacidified, ground, homogenized samples (2 mg) using the method described in Fourqurean et al. (1991).

\subsection{Statistical analyses}

For both February and July samples, percentage dry weight loss was calculated for each sample (using wet to dry weight conversion factors to estimate initial dry weight). Values were divided into coarse and fine categories, and into different species, where relevant. All data were checked for normality and heteroscedasticity and transformed where necessary. Repeated measures ANOVA was used to test for differences between the factors time, treatment, and station, along with any interactions, for the fully factorial model (that is, excluding those treatments that were not sampled at every station and time). Where significant interactions were found, further ANOVA analyses were performed within each level of the interacting factor (in order to identify significant differences between the other factors; Underwood (1997)). For the AC treatment, \% decomposition of Ceriops roots was compared (using ANOVA) with that recorded in the $C$ treatment at each station. For $\mathrm{Bn}$ and $\mathrm{Bp}$ treatments, \% decomposition was compared (using ANOVA) with that for the B treatment at the relevant stations. Crab control treatments were compared with the equivalent $B$ treatment roots at the same station.

\section{Results}

\subsection{Effects of time, species and station}

There were large differences between the decomposition rates of the species, with Avicennia decomposing faster than the other two. Mean percentage dry weights remaining after one year, for data pooled across all stations, were 24, 53, and 56 for Avicennia 
(treatment A), Bruguiera, (B) and Ceriops (C) respectively (Fig. 2). The AL treatment showed a similar pattern to that of B and C, with $58 \%$ remaining after 12 months, whilst the AM treatment was intermediate with $43 \%$. In all cases, decomposition was most rapid during the first 6 months. For example, Bruguiera roots lost 34\% of their initial mass during the first 6 months, but only 13\% in the next 6 month period.

The repeated measures ANOVA model including station, treatment and time showed highly significant differences within each factor (station: $F_{5,60}=16, \quad P<0.001$; treatment: $F_{4,60}=97$, $P<0.001$; time: $\left.F_{1,60}=78, P<0.001\right)$ but also highly significant interaction terms. Hence data were analysed using separate twoway ANOVAs for each sampling time. Data from both dates gave significant effects for treatment and station factors $(P<0.001$ for all tests apart from station in July, $P=0.036)$. However, there were highly significant interactions between the factors at both dates; these were driven in particular by the AL and AM treatments, which tended to show relatively enhanced decomposition rates at the middle stations (Fig. 3). The A treatment (i.e. nursery reared Avicennia roots) always showed the highest decomposition, on both dates and at all stations. The rank order of the other treatments varied between stations and dates, although $B, C$ and $A L$ tended to show the lowest decomposition, whilst the AM treatment tended to show the second highest.

The February ( 6 months decomposition) data showed a general trend of decreasing decomposition at the upper shore (stations 1 and 2, Fig. 3), particularly for treatments AL and AM. One way ANOVAs on the effects of station for each of the treatments individually gave highly significant results for all treatments excepting A, and in every case stations 1 or 2 showed the highest remaining mass. The station effect was less clear for the July (12 months decomposition) data, with only $\mathrm{B}$ and $\mathrm{AL}$ treatments showing significance; B showed a similar pattern to that of February, with lower decomposition at the upper shore, whilst AL showed anomalously high decomposition at station 3 (Fig. 3).

\subsection{Organic nutrient concentrations and effects}

The \% weight remaining of $\mathrm{B}, \mathrm{Bn}$, and $\mathrm{Bp}$ treatments at stations 1 and 6 were directly compared (since $B n$ and Bp treatments were restricted to these stations). The factors time, treatment and station were all highly significant (repeated measures ANOVA: $F_{1,12}=63$, $P<0.001 ; F_{2,12}=8, P=0.007 ; F_{1,12}=14, P=0.003$ respectively), with no significant interactions. Station 6 showed higher decomposition rates (Fig. 4). Bn decomposed faster than the other two

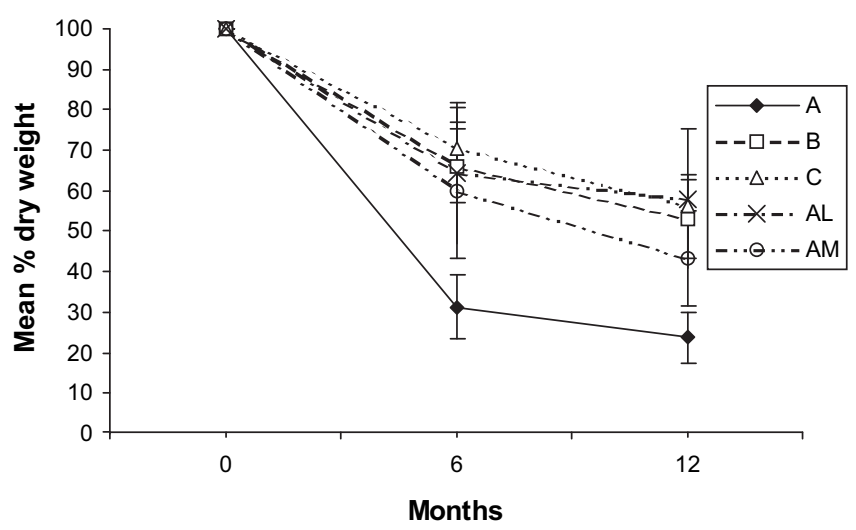

Fig. 2. Mean ( \pm S.D.) percentage dry root weight remaining in five treatments $(\mathrm{A}=$ Avicennia, $\mathrm{B}=$ Bruguiera, $\mathrm{C}=$ Ceriops, $\mathrm{AL}=$ Avicennia large, $\mathrm{AM}=$ Avicennia mature $)$ after 6 and 12 months. Data are pooled across six stations. treatments; Bn means were significantly lower than those of B and Bp, which did not differ from each other (Tukey tests; Fig. 4).

Rates of $\mathrm{N}$ and $\mathrm{P}$ loss from the roots, calculated by subtracting the amount of nutrient remaining in the roots after one year from the amount present in the initial samples, showed $A$ as exhibiting the highest rates for $\mathrm{N}$ and $\mathrm{Bp}$ the highest rates for $\mathrm{P}$ (Table 2). Although there was a net loss of $\mathrm{N}$ and $\mathrm{P}$ during the experiments the nitrogen concentration of the decomposing mangrove roots increased in all the treatments at both stations, while phosphorus concentrations all decreased. Differential rates of loss of $\mathrm{C}, \mathrm{N}$, and $\mathrm{P}$ resulted in changes to the elemental ratios. Initial organic carbon/ total nitrogen molar ratios $(C / N)$ for samples of roots of $A, B, C, B n$, and $B p$ treatments were $57,79,77,54$, and 53 respectively. In all cases the $\mathrm{C} / \mathrm{N}$ of the mangrove roots had decreased after 12 months decomposition (Fig. 5). Two way ANOVA for differences amongst 12 months data, with station ( 1 or 6 ) and treatment (A, B, C, AL, AM, Bn, Bp) as factors showed a significant treatment effect $\left(F_{6,6}=25\right.$, $P<0.001)$ and a significant treatment $\times$ station interaction $\left(F_{6,26}=3.3, P=0.014\right)$. Data were therefore analysed separately for each station; in both cases $A$ had the lowest $\mathrm{C} / \mathrm{N}$ ratio, which differed significantly $(P<0.05)$ from all treatments apart from $\mathrm{Bn}$ at station 1 , and only from AL at station 6 . Bn was significantly lower than AL, B, and $C$ at station 1 . AL had the highest $\mathrm{C} / \mathrm{N}$ at both stations, and was the only treatment to differ significantly at station 6 .

Initial organic carbon/total phosphorus molar ratios $(\mathrm{C} / \mathrm{P})$ for samples of roots of A, B, C, and Bp treatments were 1118,1317, 1021, and 1019; an error meant that a value for the Bn treatment is not available. In contrast with the total nitrogen results, decomposition did not enhance organic phosphorus concentrations; rather $\mathrm{C} / \mathrm{P}$ ratios increased in all treatments except A for station 6 after 12 months (Fig. 6). Two way ANOVA for differences amongst 12 months data, with station (1 or 6) and treatment (A, B, C, AL, AM, Bn, Bp) as factors showed a significant treatment $\left(F_{6,6}=27, P<0.001\right)$ and station $\left(F_{1,6}=59, P<0.001\right)$ effect, with no interaction - station 6 showed generally higher $\mathrm{P}$ concentrations (and hence lower $\mathrm{C} / \mathrm{P}$ values) than station 1 (Fig. 6). C/P for A was significantly $(P<0.05)$ lower than all other treatments (Tukey multiple comparison test). AL had higher mean $\mathrm{C} / \mathrm{P}$ than all other treatments, and was significantly higher than the AM, Bn and Bp treatments (Fig. 6).

\subsection{Effects of root size}

The Avicennia large (AL) treatment was significantly more refractory than the A treatment (Fig. 3; Tukey Test on data described in Section 3.1, $P<0.05$ ) suggesting larger roots from this species decompose more slowly. This difference was apparent in most of the treatments when comparing fine and coarse roots. Mean ( \pm S.D.) percentage masses remaining after 12 months of fine and coarse roots, pooled across all stations and treatments, were 40 $( \pm 17)$ and $49( \pm 20)$ respectively. The effects of size were analysed formally using a three way ANOVA on July data, with treatment (all those treatments represented at all stations and in both sizes), station and size as main factors, and bag (i.e. the bag from which any given coarse and fine roots were taken) as a nested factor within station. Treatment and size were significant $\left(F_{3,15}=45\right.$, $P<0.001 ; F_{1,5}=33, P=0.002$ respectively). There was a significant interaction term between them $\left(F_{3,15}=8, P=0.002\right)$ caused by the strong effect of size on $A$ and $B$ treatments compared with the smaller differences in AM and C treatments (Fig. 7). All other factors and interactions were non-significant.

\subsection{Effects of root mixing and experimental artefacts}

Roots recovered from the AC treatment were separated into Avicennia and Ceriops, and the \% dry mass remaining of the Ceriops 

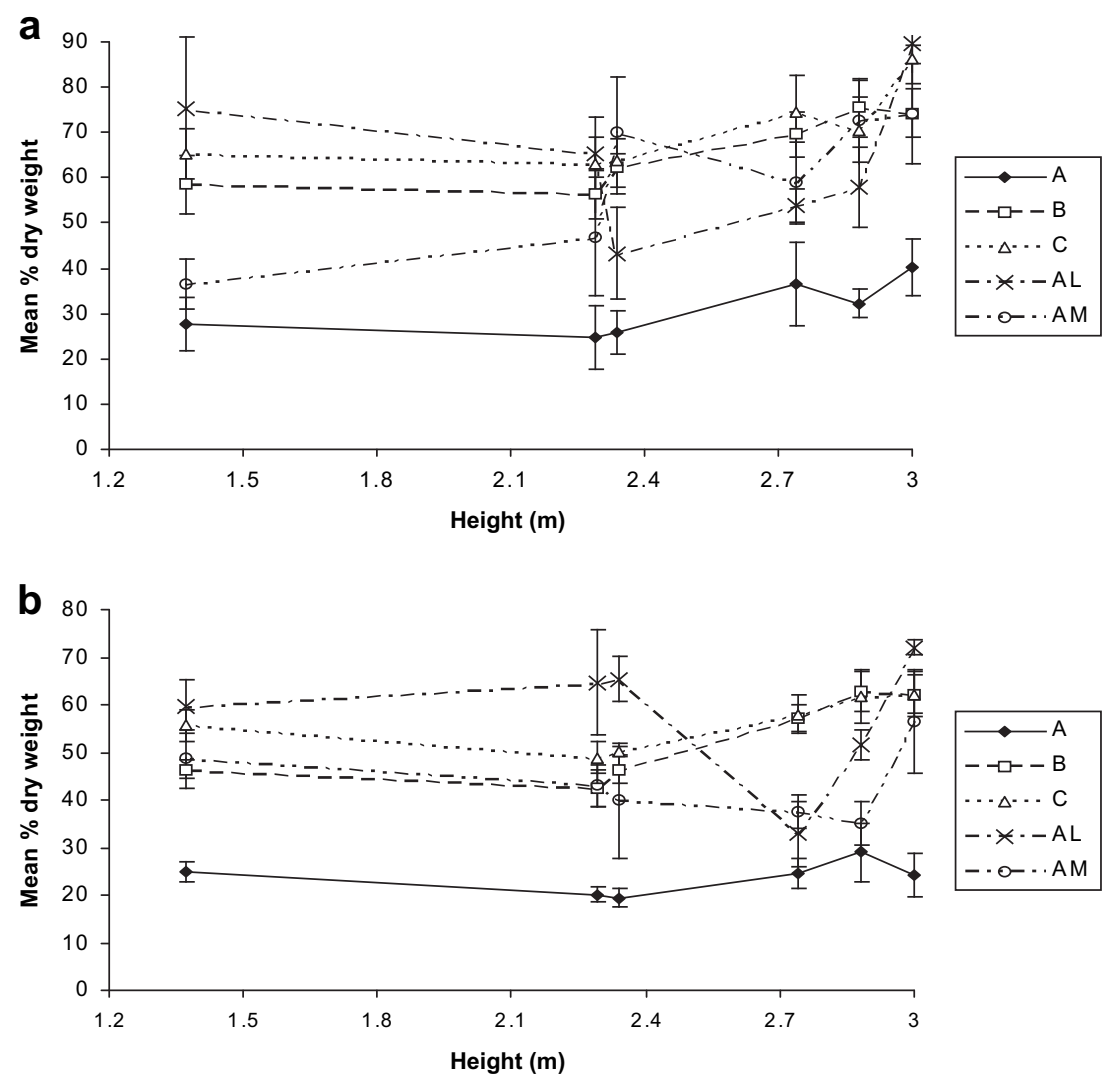

Fig. 3. Mean ( \pm S.D.) percentage dry root weight remaining in five treatments $(n=3)$ at six stations at different heights above chart datum after 6 (a) and 12 (b) months.

roots were compared with the \% mass recovered from the $C$ treatment, using a repeated measure ANOVA. There were highly significant interactions between time, station and treatment, so July data were analysed separately for each station. At stations 3, 4 and 6 a significantly $(P<0.05)$ greater \% of Ceriops roots taken from the mixed treatment had decomposed, compared with the $\mathrm{C}$ treatment (Fig. 8).

The crab control (Cc) treatment, consisting of coarse Bruguiera roots at station 4 , was compared with the coarse roots taken from the $\mathrm{B}$ treatment at the same station. The mean ( \pm S.D.) \% weights

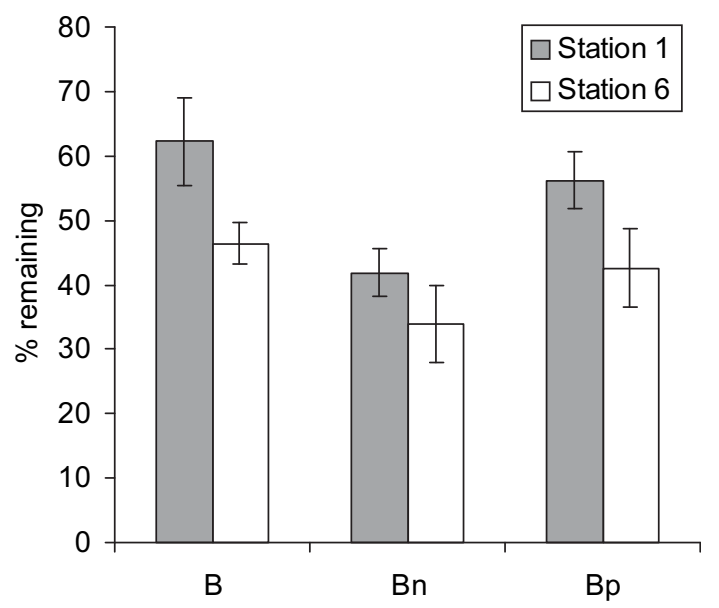

Fig. 4. Mean ( \pm S.D.) \% dry weight remaining after 12 months in the nitrogen (Bn) and phosphorus (Bp) enriched treatments at the top (1) and bottom (6) stations, compared with the un-enriched B treatment from the same stations; $n=3$ for all treatments. remaining after 6 months were very similar between treatments ( $92 \pm 4$ and $91 \pm 9$ for CC and B treatments respectively). However, after 12 months there was a higher mean \% weight in the $\mathrm{Cc}$ compared with the B treatment $(76 \pm 7 ; 56 \pm 6)$, and the difference was significant ( $t$ test $P=0.03$ ).

No roots were found in any of the growth control treatment bags, suggesting in-growth of new roots was unlikely to cause errors.

\section{Discussion}

This work is consistent with previous studies in showing generally low rates of decomposition in mangrove roots compared with other mangrove tissues (Middleton and McKee, 2001) and roots of terrestrial species (Silver and Miya, 2001). Fifty six percent of the original dry mass of the $\mathrm{C}$ (Ceriops tagal) treatment remained after one year below ground. Expressing this as a decay constant (the relationship between the natural logarithm of dry mass remaining and the time in days; Twilley et al., 1997) gives

Table 2

Rates for $\mathrm{N}$ and $\mathrm{P}$ loss from roots at stations 1 and 6, for Avicennia (A), Bruguiera (B), Ceriops (C), Bruguiera plus phosphorus (Bp) and Bruguiera plus nitrogen (Bn) treatments. Units are $\mathrm{mg} \mathrm{gDW}^{-1} \mathrm{yr}^{-1}$, using initial root DW.

\begin{tabular}{llllll}
\hline Treatment & $\mathrm{N}$ & & $\mathrm{P}$ & \\
\cline { 2 - 3 } \cline { 5 - 6 } & Station 1 & Station 6 & & Station 1 & Station 6 \\
\hline $\mathrm{A}$ & 3.93 & 4.32 & & 0.62 & 0.62 \\
$\mathrm{~B}$ & 1.13 & 1.70 & & 0.45 & 0.51 \\
$\mathrm{C}$ & 0.82 & 1.38 & & 0.66 & 0.68 \\
$\mathrm{Bp}$ & 1.92 & 2.80 & & 0.69 & 0.75 \\
$\mathrm{Bn}$ & 3.81 & 5.03 & & \\
\hline
\end{tabular}




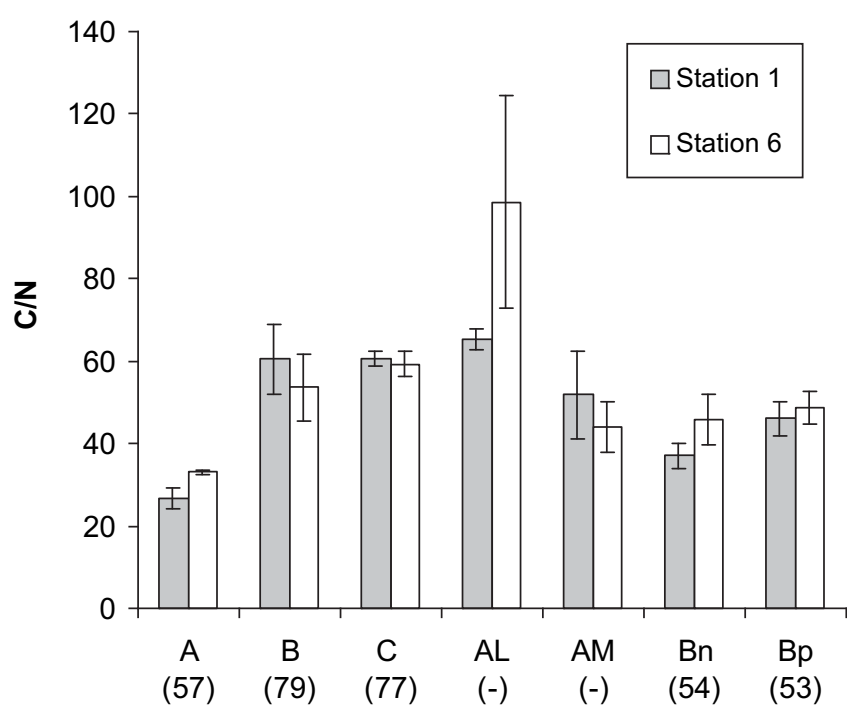

Fig. 5. Mean ( \pm S.D.) C/N values for seven treatments $(n=3)$ collected from the top (1) and bottom (6) stations on an intertidal transect after 12 months decay; numbers in parentheses are initial values where available.

$0.0012 \mathrm{~d}^{-1}$. This is similar to the lowest values recorded by Poret et al. (2007) in their study of decomposition of mixed Rhizophora mangle, Avicennia germinans, Laguncularia racemosa and Conocarpus erectus roots over 250 days, and to the mean values reported by Mckee and Faulkner (2000) after one year of decomposition in their Rhizophora mangle, Avicennia germinans and Laguncularia racemosa treatments. The A treatment, however, decayed at significantly greater rates at all stations and both times; the average decay constant of $0.0039 \mathrm{~d}^{-1}$ was higher than that reported by Poret et al. (2007) for any of their treatments, and equal to the fastest decay recorded by McKee et al. (2007) for their single Rhizophora mangle treatment.

This strong effect of species, with Avicennia marina showing consistently greater decomposition rates, has not been shown before. The studies by Mckee and Faulkner (2000) and Middleton and McKee (2001) that compared decay rates between Rhizophora mangle, Avicennia germinans and Laguncularia racemosa

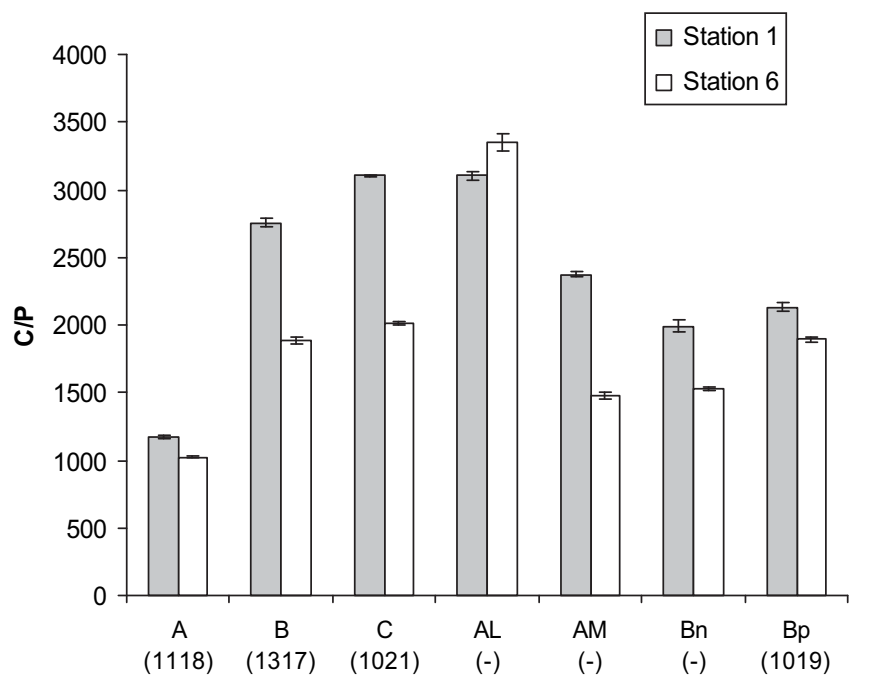

Fig. 6. Mean ( \pm S.D.) C/P values for seven treatments $(n=3)$ collected from the top (1) and bottom (6) stations on an intertidal transect after 12 months decay; numbers in parentheses show initial values where available.

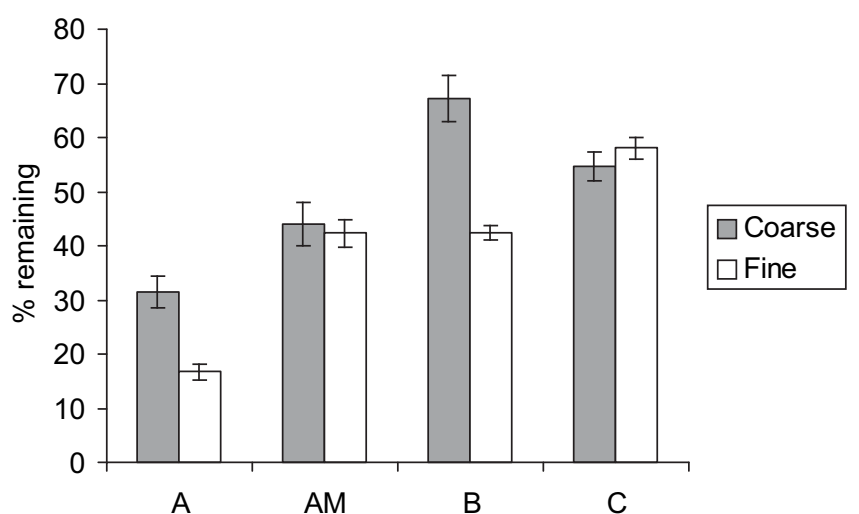

Fig. 7. Mean ( \pm S.D.) \% dry weight remaining after 12 months decay for fine $(<3 \mathrm{~mm}$ diameter) and coarse ( $>3 \mathrm{~mm}$ diameter) roots; data are for all stations combined $(n=18)$.

collected from the field found no consistent effects of species. The current study is the first to compare decay rates amongst the set of species used here; hence the differences found could be specific to these particular species. However, differences in root age, which were controlled for in the current work, may have acted as a confounder in the previous studies that used wild harvested roots.

One explanation for the differences between species is the different nutrient concentrations found in the mangrove roots. Avicennia marina had a low initial $\mathrm{C} / \mathrm{N}$ ratio (57), and it was the species with the highest initial concentration of $\mathrm{N}$ ( $0.67 \mathrm{wt} \%$ ). A. marina also accumulated the greatest $\mathrm{N}$ during decomposition (station 11.16 , station $61.00 \mathrm{wt} \%$ ), resulting in the lowest C:N (station $1, \mathrm{CN}=27$, station $6, \mathrm{CN}=33$, Fig. 5) after 12 months decomposition. In the current study, nitrogen was probably more important in stimulating decomposition than phosphorus. Despite its much faster decomposition, A. marina had a lower initial $\mathrm{P}$ concentration $(0.76 \pm 0.015 \mathrm{wt} \%)$ than $\mathrm{C}(0.85 \pm 0.045 \mathrm{wt} \%)$ or $\mathrm{Bp}$ $(0.89 \pm 0.002 \mathrm{wt} \%)$. The Bn (nitrogen enriched Bruguiera) treatment, with root nitrogen concentrations higher than the Bruguiera gymnorrhiza roots, showed significantly greater decomposition compared with the B (un-enriched) treatment; no significant difference was found for the Bp treatment. Many studies have reported differences in decay rates between leaves from different

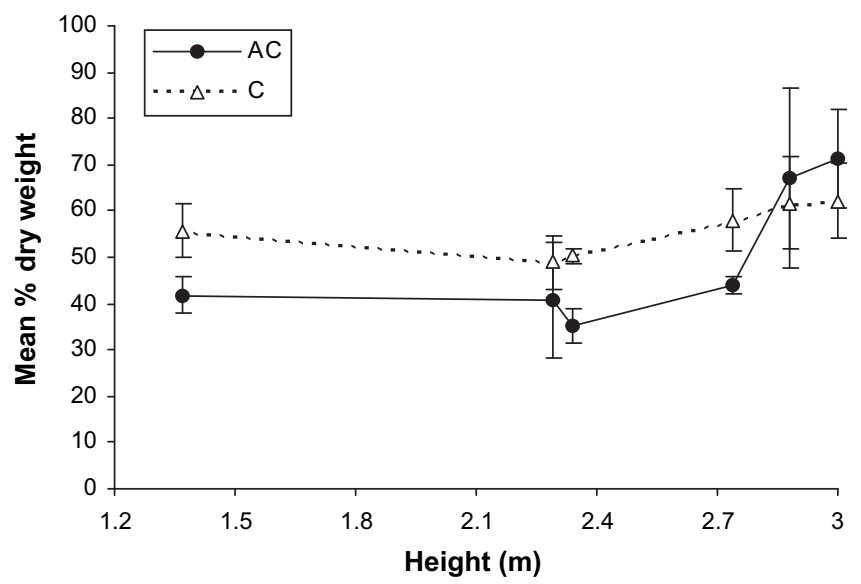

Fig. 8. Mean $( \pm$ S.D. $) \%$ dry mass remaining after 12 months from the $C$ treatment and the Ceriops roots taken from the AC treatment at 6 stations at different heights above chart datum $(n=3)$. 
mangrove species, with $\mathrm{C} / \mathrm{N}$ ratios invoked as one explanatory factor (e.g. Feller et al., 1999; Mckee and Faulkner, 2000; Bosire et al., 2005). More generally, a meta-analysis of decomposition studies across eight different ecosystems (including mangroves) demonstrated a strong relationship between nitrogen content and decomposition rates (Cebrian et al., 1998). Hence it might be expected that lower $\mathrm{C} / \mathrm{N}$ would result in faster decomposition in roots also, as reported here. Poret et al. (2007) found no effects of $\mathrm{C} / \mathrm{N}$ on root decomposition, although their study involved mixed roots of different ages and from different sites, hence small effects of C/N may have been masked. Feller et al. (1999) found enhanced sediment $\mathrm{P}$ concentrations increased decomposition rates in buried cotton strips, whilst enhanced $\mathrm{N}$ concentrations had no effects. It is likely that the limiting factor ( $\mathrm{N}$ or $\mathrm{P}$ ) will vary between sites, but the current results are consistent with the broader decomposition literature in suggesting $\mathrm{N}$ concentration of roots may be important. In common with studies on mangrove leaves (e.g. Fourqurean and Schrlau, 2003) and wood (Romero et al., 2005), C/N ratios dropped during decomposition, as roots became relatively enriched with $\mathrm{N}$ by microbial activity; the accumulation of refractory root material with enhanced $\mathrm{N}$ levels represents a storage mechanism for nutrients within the mangrove ecosystem (Alongi, 2009, p. 107). $P$ levels remained similar or reduced over time.

Enhanced N concentrations in Avicennia roots (initial concentration $0.67 \pm 0.012 \mathrm{wt} \%$ ) that were intimately mixed with Ceriops roots (initial concentration $0.51 \pm 0.046 \mathrm{wt} \%$ ) are the most likely explanation for the faster decomposition of Ceriops roots found in the AC treatment. Similar results, with multi-species mixes enhancing decomposition in refractory species, have been recorded in some terrestrial leaf studies (Madritch and Cardinale, 2007), but not to our knowledge for mangroves (e.g. Ashton et al., 1999). It therefore seems that root decomposition will differ between mixed versus mono-specific stands.

Poret et al. (2007) and Mckee and Faulkner (2000) compared sites with different hydrological regimes, and reported slower root decomposition rates at wetter sites with lower redox potentials. This differs from the pattern found here of generally faster decomposition at lower tidal stations, despite redox values below those reported by Poret et al. (2007) and Mckee and Faulkner (2000). Hence redox alone does not predict decomposition (perhaps because it can be a poor surrogate for oxygen availability). Both of these studies refer to water logging and incomplete tidal flushing at the sites with slow decomposition; in contrast, the lower stations at Gazi were flushed daily by the tide, and thus may have experienced less extreme hydro-chemical regimes. Romero et al. (2005) found that mangrove wood decomposed faster when buried than when dry. It is possible that the relatively dry conditions at the highest Gazi stations, combined with the high levels of salt, acted to reduce decomposition. However, the treatment $\times$ site interactions suggest that substrate and site variables will interact to determine specific decomposition rates; the AL (large Avicennia roots) and AM (roots from mature Avicennia trees) treatments showed the most unusual interactions, and these were the treatments using 'ambient' roots with no knowledge of their age, and hence with the greatest likely variability in nutrient composition.

Macrofauna such as snails and crabs may consume a large fraction of mangrove leaf detritus, leading to underestimation of degradation rates of leaves in studies using mesh bags, which exclude such organisms (Mckee and Faulkner, 2000). To our knowledge, there are no studies on consumption of roots by macrofauna, and the purpose of our crab control treatment was to provide a test of this possible artefact. There was no evidence that mesh bags were preventing decomposition (implying that macrofauna were not important agents of decomposition of roots although this does not preclude indirect effects through for example oxygenation of the sediment (Kristensen, 2008)). Rather, there was significantly less weight loss in the un-bagged roots. This suggests that the mesh bags could enhance decomposition, perhaps by fostering a wet or nutrient-rich microenvironment. This is one of four reasons why the decomposition rates reported here are likely to be fast compared with natural conditions. The other three are: (1) root age. To allow treatment comparisons unconfounded by age differences, roots of the same age from seedlings were used. Such roots are likely to be less lignified, and perhaps more nutrient rich, than older roots, and hence should decay more rapidly. The significantly slower decay recorded for the AM (Avicennia mature) compared with the A treatment supports this. (2) Root status. Living (or newly killed) root material was used. Rhizophora mangle trees may recover $\sim 40-70 \%$ of $\mathrm{N}$, and $\sim 20-70 \%$ of $\mathrm{P}$, from their leaves during senescence (Feller et al., 1999). If a similar resorption occurs in roots, then decay is likely to be slower because of lower nutrient concentrations. (3) Root size. Coarse roots tended to decompose more slowly than fine ones (Fig. 7), and the AL treatment was more refractory than the other Avicennia treatments. Hence using one-third fine roots may have led to fast overall decomposition rates. However, fine roots do constitute a major part of root biomass at Gazi, with roots $<5 \mathrm{~mm}$ in diameter contributing $53-37 \%$ of dry weight depending on species (Tamooh et al., 2008).

\section{Conclusion}

This work is consistent with the few previous studies on mangrove root decomposition in finding slow decay rates, ranging from 24 to $58 \%$ of dry weight lost over one year, and there are reasons to suspect that these may over-estimate the speed of decay. Given below ground biomass of up to $75 \mathrm{t} / \mathrm{ha}$ at our site (Tamooh et al., 2008) this supports the notion of mangrove forests as furnishing long term carbon sinks (Komiyama et al., 2008). Rates of decomposition (and hence ultimately carbon accumulation) at Gazi depend on site and species. Future mangrove restoration and management plans might choose carbon accumulation as a key objective; if so, this may require balancing the attractions of more productive sites (lower tidal) and species (Avicennia) against conditions with slower decay (e.g. drier sites with slower growing species such as Ceriops - Kirui et al., 2008).

\section{Acknowledgements}

This work was supported by The Earthwatch Institute and The Rufford Trust. We are grateful to the Earthwatch volunteers and $\mathrm{Mr}$ Laitani Suleiman who assisted in the field and to the people of Gazi who hosted us. The manuscript was improved thanks to the comments of the editor and two anonymous referees.

\section{References}

Albright, L.J., 1976. In situ degradation of mangrove tissues. New Zealand Journal of Marine and Freshwater Research 10, 385-389.

Alongi, D.M., 2009. The Energetics of Mangrove Forests. Springer, London, 216 pp. Ashton, E.C., Hogarth, P.J., Ormond, R., 1999. Breakdown of mangrove leaf litter in a managed mangrove forest in Peninsular Malaysia. Hydrobiology 413, 77-88.

Bosire, J.O., Dahdouh-Guebas, F., Kairo, J.G., Kazungu, J., Dehairs, F., Koedam, N., 2005. Litter degradation and $\mathrm{CN}$ dynamics in reforested mangrove plantations at Gazi Bay, Kenya. Biological Conservation 126, 287-295.

Bosire, J.O., Dahdouh-Guebas, F., Kairo, J.G., Koedam, N., 2003. Colonization of nonplanted mangrove species into restored mangrove stands in Gazi bay, Kenya. Aquatic Botany 76, 267-279.

Bouillon, S., Borges, A.V., Diele, K., Dittmar, T., Duke, N.C., Kristensen, E., Lee, S.Y., Marchand, C., Middelburg, J.J., Rivera-Monroy, V.H., Smith- III, T.J., Twilley, R.R. Castaneda-Moya, E., 2008. Mangrove production and fate: a revision of budget estimates. Global Biogeochemical Cycles 22, GB2013. doi:10.1029/ 20007 GB003052. 
Briggs, N., 1977. Estimates of biomass in a temperate mangrove community. Australian Journal of Ecology 2, 369-373.

Cahoon, D.R., Hensel, P., Rybczyk, J., McKee, K.L., Proffitt, E., Perez, B.C., 2003. Mass tree mortality leads to mangrove peat collapse at Bay islands, Honduras after Hurricane Mitch. Journal of Ecology 91, 1093-1105.

Cebrian, J., Williams, M., MacClelland, J., Valiela, I., 1998. The dependence of heterotrophy and carbon accumulation on autotrophic nutrient concentration in ecosystems. Ecology Letters 1, 165-170.

Duarte, C.M., Middelburg, J.J., Caraco, N., 2005. Major role of marine vegetation on the oceanic carbon cycle. Biogeosciences 2, 1-8.

Feller, I.C., Whigham, D.F., O'Neill, J.P., McKee, K.L., 1999. Effects of nutrient enrichment on within-stand cycling in a mangrove forest. Ecology 80, 2193-2205.

Fourqurean, J.W., Schrlau, J.E., 2003. Changes in nutrient content and stable isotope ratios of $C$ and $N$ during decomposition of seagrasses and mangrove leaves along a nutrient availability gradient in Florida Bay, USA. Chemical Ecology 19, 373-390.

Fourqurean, J.W., Zieman, J.C., Powell, G.V.N., 1991. Phosphorus limitation of primary production in Florida Bay, Evidence from C: N:P ratios of the dominant seagrass Thalassia testudinum. Limnology and Oceanography 37, 162-171.

IPCC (Intergovernmental Panel on Climate Change), 2007. Climate change 2007: synthesis report. A Report of the Intergovernmental Panel on Climate Change. Cambridge University Press, Cambridge, 73 pp.

Jennerjahn, T.C., Ittekkot, V., 2002. Relevance of mangroves for the production and deposition of organic matter along tropical continental margins. Naturwissenschaften $89,23-30$

Kirui, B., Huxham, M., Kairo, J., Skov, M., 2008. Influence of species richness and environmental context on early survival of replanted mangroves at Gazi bay, Kenya. Hydrobiologia 603, 171-181.

Komiyama, A., Ong, J.E., Poungparn, S., 2008. Allometry, biomass, and productivity of mangrove forests: a review. Aquatic Botany 89, 128-137.

Kristensen, E., 2008. Mangrove crabs as ecosystem engineers; with emphasis on sediment processes. Journal of Sea Research 59, 30-43.

Madritch, M.D., Cardinale, B.J., 2007. Impacts of tree species diversity on litter decomposition in northern temperate forests of Wisconsin: a multi-site experiment along a latitudinal gradient. Plant and Soil 292, 147-159.
McKee, K.L., Cahoon, D.R., Feller, I.C., 2007. Caribbean mangroves adjust to rising sea level through biotic controls on change in soil elevation. Global Ecology and Biogeography 16, 545-556.

Mckee, K.L., Faulkner, P.L., 2000. Restoration of Biogeochemical Function in Mangrove Forests. Restoration Ecology 8, 247-259.

Middelburg, J.J., Nieuwenhuize, J., Slim, F.J., Ohowa, B., 1996. Sediment biogeochemistry in an East African mangrove forest (Gazi Bay, Kenya). Biogeochemistry $34,133-155$.

Middleton, B.A., McKee, K., 2001. Degradation of mangrove tissues and implications for peat formation in Belizean island forests. Journal of Ecology 89, $818-828$.

Poret, N., Twilley, R.R., Rivera-Monroy, V.H., Coronado-Molina, C., 2007. Belowground decomposition of mangrove roots in Florida coastal everglades. Estuaries and Coasts 30, 491-496.

Romero, L.M., Smith, T.J., Fourqurean, J.W., 2005. Changes in mass and nutrient content of wood during decomposition in a south Florida mangrove forest. Journal of Ecology 93, 618-631.

Saintilan, N., 1997. Above- and below-ground biomass of mangroves in a subtropical estuary. Marine Freshwater Research 48, 601-604.

Silver, W.L., Miya, R.K., 2001. Global patterns in root decomposition: comparisons of climate and litter quality effects. Oecologia 129, 407-419.

Tamooh, F., Kairo, J.G., Karachi, M., Huxham, M., Mencuccini, M., 2008. Vertical and horizontal below-ground root distribution in natural and replanted mangrove forest in Gazi Bay, Kenya. Forest Ecology and Management 256, 1290-1297.

Twilley, R.R., Pozo, M., Garcia, V.H., Rivera-Monroy, V.H., Zambrano, R., Bodero, A. 1997. Litter dynamics in riverine mangrove forests in the Guayas River estuary, Ecuador. Oecologia 111, 109-122.

Underwood, A.J., 1997. Experiments in Ecology. Cambridge University Press, Cambridge, 504 pp.

Van der Valk, A.G., Attiwill, P.M., 1984. Decomposition of leaf and root litter of Avicennia marina at Westernport Bay, Victoria, Australia. Aquatic Botany 18, 205-221.

Watson, J.G., 1928. Mangrove forests of the Malay peninsular. Malayan Forest Records 6, 1-275. 